\title{
FIRM SIZE, TECHNOLOGICAL CAPABILITY, EXPORTS AND ECONOMIC PERFORMANCE: THE CASE OF ELECTRONICS INDUSTRY IN MALAYSIA
}

\author{
V. G. R. Chandran ${ }^{1}$, Rajah Rasiah ${ }^{2}$ \\ ${ }^{1}$ Department of Development Studies, Faculty of Economics and Administration, University of \\ Malaya, 50603 Kuala Lumpur, Malaysia \\ ${ }^{2}$ Department of Economics, Faculty of Economics and Administration, University of Malaya, \\ 50603 Kuala Lumpur, Malaysia \\ E-mails: ${ }^{1}$ vgrchan@gmail.com (corresponding author); ${ }^{2}$ rajah@um.edu.my \\ Received 03 January 2012; accepted 20 February 2012
}

\begin{abstract}
This paper examines the joint effects of technology and exports on the economic performances of electronics firms in Malaysia. The empirical results based on the Partial Least Square (PLS) estimate procedure show that technological capability plays a multiple role in that it influences both the exports and performance of a firm simultaneously. More importantly, we find evidence that exports act as a mediating variable between technological capability and firm performance. Size is found to influence all three: product capabilities, exports and firm performance but not process capabilities. This paper concludes that researchers, in future studies, need to examine the dynamism between size, technology, exports and performance.
\end{abstract}

Keywords: technology, size, exports, economic performance, Malaysia.

Reference to this paper should be made as follows: Chandran, V. G. R.; Rasiah, R. 2013. Firm size, technological capability, exports and economic performance: the case of electronics industry in Malaysia, Journal of Business Economics and Management 14(4): 741-757.

JEL Classification: O30, F14, L25, L60, L63.

\section{Introduction}

Studies examining the influence of internal and external factors (or resources) on firm performance are plenty (Barney, Ouchi 1986; Barney 1991). A large number of researches focus on the influence of technology on performance (Hitt et al. 2000) and many, among them, have also investigated the relationship among technology, exports and firm performance. Yet, the debate on technological capability, exports and economic performance has remained inconclusive. Likewise, issues of how they are related are less understood (Barney et al. 2001; Strandskov 2006). A large number of studies (Andersen, Foss 2005; Buckley, Casson 1991; Duysters, Hagedoorn 2000; Henderson, 
Cockburn 1994; Karagozoglu, Lindel 1998; Kim, Nelson 2001; Nelson 1991; Teece et al. 1997; Tsai 2004; Rasiah 2007) focus only on the direct relationship between technology and performance as well as technology and exports. Similarly, at firm level, technological capability serves as a major source of export competitiveness (Ernst et al. 1998; Rasiah 2004; Iammarino et al. 2008; Wignaraja 2008a). However, these studies ignore the complex relationship between the variables and lack the dynamic analysis that analyses the joint effects of technology and exports on performance. Furthermore, size or scale that is of importance for the manufacturing sectors (Cohen, Klepper 1996; Mittelstaedt et al. 2003; Sterlacchini 1999) is less explored in a dynamic way. In other words, size can play an important role in influencing technology capability, exports as well as performance jointly. Despite significant advancement in theories, there are still large gaps in understanding the critical issues in hand (Barney et al. 2001; Strandskov 2006). For instance, technology may have an impact on exports and in return, exports may enhance firm performance. Similarly, size may affect technology, exports and performance. Hence, ignoring the joint or indirect effects of technology on performance may lead to the overlooking of certain critical dimensions in understanding the relationship among technology, exports and performance.

Owing to the existing research gap, this paper attempts to make an analysis of the relationship between technology and performance via the mediating role of exports and the impact of firm size on technology, exports and performance. By examining the complex relationship among firm size, technology, exports and performance, this paper contributes in providing a complete picture showing the interrelationship among the variables under study. Indeed, the empirical evidence contributes to the methodological and theoretical understanding on the issues of technology, export and overall firm performance. To meet this objective, this paper uses the Partial Least Square (PLS) method to analyse the joint effects of technology and exports on firm performance. Furthermore, the paper attempts to provide clarification and further understanding, for reasons both conceptual and methodological.

The rest of the paper is organised as follows. Section 2 discusses the theoretical justification of the relationship among technological capability, exports and performance. Section 3 outlines the data source and methodology employed in the paper. Section 4 discusses the results and implications of policies, followed by the conclusion in Section 5 .

\section{Theoretical considerations}

This section reviews the important works that have been discussed on the relationship among technological capability, size, export and firm performance. It seeks to establish the critical hypotheses that will be examined subsequently.

\subsection{Technological capability and exports}

In attempting to explain export behavior, researchers have investigated extensively the antecedents of exports. Resources owned by firms, from the point of view of resource- 
based theories, are regarded as one of the important factors (Barney 1986, 1991; Conner, Prahalad 1996; Penrose 1959). Among a firm's resources, technological capability is regarded as one of the crucial assets of a firm in determining export performance (Buckley, Casson 1991; Dhanaraj, Beamish 2003; Hitt et al. 2000; Karagozoglu, Lindel 1998; Teece et al. 1997). The role of technological capability is seen as strengthening the competitive advantage of firms in export markets. Using a more detailed innovative capability dimension (e.g learning, research and development (R\&D), manufacturing, marketing, organising, resource allocation and strategy planning), Guan and Ma (2003) investigate the relationship between innovative capabilities and exports. The results suggest that the overall improvements in innovative capability have a significant and positive relationship on export growth. Across nations, a number of studies using different proxies of technology at the firm level have established the positive relationship between technology and export performance. Kumar and Siddharthan (1994) who did their studies on India, Ito and Pucik (1993) on Japan, Wignaraja (2002, 2008b) on Mauritus and Sri Lanka, and Rasiah $(2004,2006)$ on Malaysia, Thailand, Indonesia and South Africa find technological activities to significantly influence export performances. Similarly, Zhao and Li (1997) and Pla-Barber and Alegre (2007) also report a similar result. Hence, we hypothesise that technological capability has a positive effect on exports.

\subsection{Technological capability and economic performance}

The relationship between innovation and economic performance is well established at the macro and micro levels which have been the main argument in economic growth and literature on firm performance (Romer 1990; Solow 1957; Stock et al. 2001; Wakelin 2001). The pioneering work of Chandler (1962) recognises the crucial importance of technology and innovation to a firm's survival and competitiveness. To achieve a competitive advantage at firm level, technological capability is important (Andersen and Foss 2005; Duysters, Hagedoorn 2000; Henderson, Cockburn 1994; Kim, Nelson 2001; Lall 1992; Nelson 1991; Tsai 2004). Technological capability is regarded as a positive source of competitive advantage that leads to an increase in firm performance (Barney 1991; Cardozo et al. 1993; Chandy, Tellis 1998; Geroski et al. 1993; Yeoh, Roth 1999). Similarly, using patent data, as well as research and development expenditure as the proxy for innovation, Griliches (1986) and Duysters and Hagedoorn (2000) demonstrate the importance of technological progress on performance ${ }^{1}$.

Other firm level studies using appropriate proxies of technological capabilities for developing countries include Rasiah (2006, 2007), Figueiredo (2002a, 2002b), and Wignaraja (2002) who show the importance of technological capability on firm performance. Studies examining the small and medium enterprises also find that levels of technology and learning capabilities are significantly important for firm performance (OyelaranOyeyinka, Lal 2006). As a whole, the technological profile of a firm or its innovation capabilities is considered a relevant resource to achieve competitive advantage (Yeoh,

\footnotetext{
${ }^{1}$ It is argued that total factor productivity as well as the use of patents and R\&D expenditure as a proxy for innovation is less appealing especially in developing countries (Nelson 1981; Hobday 1996, 2005)
} 
Roth 1999). Since the literature on the impact of innovation and performance is consistent, little effort is needed in this study to establish the theoretical link between the two. The above arguments demonstrate that there is a direct relationship between technology capability and performance.

\subsection{Exports and economic performance and its mediating effects}

A growing theory posits that exports play an important role in driving economic growth. Smith (1776), Young (1928) and Hirschman (1958) argue that exports expand market size and competition. Schumpeter (1934) and Solow (1956) identify technology (innovation) as the vehicle through which competitiveness (productivity) is achieved. The international literature posits a positive relationship between a degree of internationalisation of a firm and its performance (Delios, Beamish 1999; McDougall, Oviatt 1996). While firms participating in export markets can necessarily improve their competitiveness, the relationship between exports and performance may not be direct. Technological capability may offer export markets the scale of learning and knowledge by competing, which in turn may influence performance. In this way, exports may have both direct and indirect effects on performance. Dhanaraj and Beamish (2003) confirm that innovation influences performance indirectly via exports. Hence, we hypothesise that export mediates the relationship between technological capabilities and firm performance.

\subsection{Size, technological capability, exports and performance}

Schumpeter (1934) posits that R\&D expenditure or R\&D intensity is associated with large firm benefits. The established evidence in this relationship however, receives mixed reactions. Link (1981), Cohen and Klepper (1996), and Wignaraja (2002, 2008b) provide evidence that size is positively correlated to research performance. However, Audretsch and Acs (1991) and Graves and Langowitz (1993) find R\&D and firm size to be negatively related. Hence, as a whole, there are mixed views of how R\&D intensity is related to firm size. Similarly, owing to resources and scale advantage, larger firms tend to have better export intensities and overall performances. Firm size as an indicator of a firm's organisation, finance and managerial resources should be considered an important factor in determining performance (Penrose 1959; Barney 1991). Hence, most studies tend to posit a positive relationship between size and exports (Mittelstaedt et al. 2003; Sterlacchini 1999). Large firms are assumed to have large scale capabilities to participate in export markets. In addition, the amount of design, engineering and preproduction development is found to positively impact the share of exports. Industrial organisation exponents argue that scale size offers a minimum efficient size to lower unit costs (Scherer 1984). In light of the mixed views and differing evidences, a neutral hypothesis is established for the relationship among size and exports, technological capability and economic performance.

\section{Methodology and data}

This section discusses the analytical framework and the data source employed for the paper. The technological approach taken is the evolutionary concept of technological 
capability rather than the neoclassical concept of total factor productivity. The proxies of technology are embodied in capital, workforce, processes and products.

\subsection{Analytical framework}

Based on the literature review, we have developed a framework for analysis depicted in Fig. 1, and consequently tested the hypotheses of the study. Unlike previous studies that only examined the role of technological capability on exports or performance separately, this paper examines whether or not technological capability affects performance via the mediating role of exports. In other words, the joint effects of technological capability and export intensity on performance are examined in the same model. We use the partial least square technique to undertake this exercise. This framework also allows the examination of other effects - e.g. technological capability and size on firm performance.

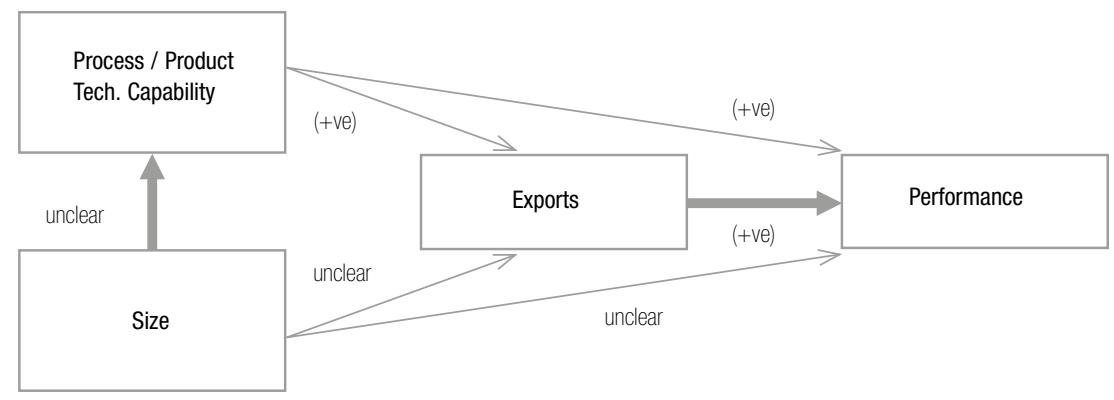

Fig. 1. Framework of analyses

\subsection{Data and sample}

The data used in this paper comes from the authors' survey of electronics firms undertaken in Penang between August 2008 and January 2009 through face-to-face interviews and a questionnaire survey. The purpose of the interviews was to get a better insight on the profile of the firms and to understand the technological capabilities of firms. The data collected using the questionnaire forms the basis for examining the hypotheses. The population of the study comprises all the electronics firms in Penang listed by Malaysian Industrial Development Authority (MIDA) and InvestPenang, a non-governmental agency. The authors distributed 250 questionnaires to the top management of the selected firms. The structured sampling procedure takes ownership and size into account. Out of the 250 questionnaires, a total of 100 questionnaires were returned and only 99 are usable in the sense that all three variables could be computed using the returned questionnaires. The sampling represents $40 \%$ of the total population. To check the content validity of the reported values, the authors use data triangulation. Data on sales, output, research and development expenditure, employment and exports were also obtained from the Malaysian Commissions of Companies and annual reports of the respective firms. The secondary data was then cross checked with the reported data in the questionnaires. Correlation analysis between the data obtained from secondary sources 
(e.g. on sales, value added output, employment) and the reported values were high and significant. It suggests that there is high similarity between the secondary data and the reported data. Since the measurements used in this paper are quantitative and objective, compared to studies using perceived constructs, there are no issues of construct validity and response-biasness as in the case of the use of Likert-scale measurement.

The electronics industry, in particular, firms in Penang, was chosen as a case study mainly due to its high export intensity (Rasiah 2010) and also the fact that the industry has been the main contributor to the overall manufacturing exports of Malaysia. Secondly, existing evidence on the electronics industry in Malaysia supports the presence of technological learning and upgrading (Hobday, Rush 2007; Lall 2001; Rasiah 1994). Hobday (1996) highlights significant incremental and process innovation in electronics firms in Penang, making electronics sectors an interesting case to study. Indeed, the knowledge content of this industry is fairly well developed (Shapira et al. 2006). The choice of Penang as the location for research is further motivated by the following factors. Firstly, Penang has the largest concentration of electronics firms in Malaysia (Rasiah 2007). Secondly, Penang has achieved a higher level of technological upgrading than other parts of Malaysia (Rasiah 2007). Lai and Narayanan (1999) note that Penang has a long-established MNC-local firm linkage with a great specialisation that promotes exports and innovation. Other firm level studies (e.g. Abibullah et al. 1994; Ariffin, Bell 1999; Ariffin, Figueiredo 2004; Hobday 1999; Narayanan, Lai 2000; Rasiah 1994) show that technological upgrading among local firms are the results of integration within the global production network (e.g. via equity and exports).

Table 1 shows the number and profile of respondents based on firm size. The results indicate that our sample is representative of the total electronics sector population on demographic-related items, namely size. Pavitt (1984) and Pavitt et al. (1987) have highlighted the differences in technological and innovation activities across industries. Obviously, process technology will differ greatly if one takes the manufacturing sector as a whole compared to only the electronics sub-sector. The focused attention on electronics firms help support in-depth analysis and prevents the misrepresentation of technological variables. Table 1 indicates that there are differences in all the variables under investigation as size increases, implying that size may be an important determinant for technology, export and performance.

Table 1. Sample profile by size and mean values, 2006

\begin{tabular}{llllll}
\hline $\begin{array}{l}\text { Size } \\
\text { No. of } \\
\text { Employees) }\end{array}$ & $n(\%)$ & $\begin{array}{l}\text { Value Added } \\
\text { Output } \\
\text { (RM millions) }\end{array}$ & $\begin{array}{l}\text { Product } \\
\text { Technological } \\
\text { Capability (RD) }\end{array}$ & $\begin{array}{l}\text { Process } \\
\text { Technological } \\
\text { Capability (PT) }\end{array}$ & $\begin{array}{l}\text { Export } \\
\text { Intensity } \\
\text { (EI) }\end{array}$ \\
\hline Under 100 & $27(27.2)$ & 3.7 & 0.045 & 0.31 & 0.54 \\
\hline Over 100-500 & $36(36.4)$ & 17.3 & 0.048 & 0.40 & 0.65 \\
\hline Over 500-1000 & $16(16.2)$ & 61.5 & 0.123 & 0.41 & 0.82 \\
\hline Over 1000 & $20(20.2)$ & 238.0 & 0.211 & 0.45 & 0.90 \\
\hline
\end{tabular}

Note: Refer to Section 3.2 for details on measurements.

Source: Computed from Electronics Cluster Survey, 2008. 


\subsection{Measurement}

In this sub-section, we specify the critical explanatory and control variables. The paper avoids the use of the neoclassical framework of technology - both the orthodox version advocated by Solow (1956) and the adapted one, following revisions, advocated by the new growth exponents (Grossman, Helpman 1991; Krugman 1979, 1986; Lucas 1988; Romer 1986). As noted by Nelson (1973) and Lall (1998), both neoclassical versions of technology distort embodied technology. Moreover, the estimation of technology as a black box using the production function is inappropriate (Hobday 2005; Rasiah 2006). Hence, the paper uses the evolutionary framework of technological capability (see Nelson 2008).

\subsubsection{Technological capability}

The study on capabilities can be traced to Penrose (1959) and Andrews (1971). Penrose (1959) indicates that although resources are available in all firms, capability, which is important for the deployment of resources productivity is unevenly distributed among firms. In the same vein, technological capability refers to the ability of firms to deploy its technology. The specific categories, phases, and processes of technological change are analysed by Rosenberg (1982) who was among the earliest to call for the unbundling and examining of technology inside the black box. Rosenberg and Firschtak (1985) define technological capability as a process of accumulating technical knowledge or a process of organisational learning. Dahlman et al. (1987) emphasise the underlying concept of trajectory of deepening capability, moving from technology-using production capabilities to innovation-driving capabilities. They develop a sequence of capabilities running from production capability via investment capability to innovation capability, which is consistent with Dosi's (1982) and Pavitt's (1984) taxonomy of technological capabilities. Lall (1992) subsequently outlines a functional categorisation of technological capabilities based on the tasks facing a manufacturing firm. The tasks and associated capabilities are catagorised into two groups: investment capabilities and production capabilities. These are further divided into three levels. The first level is simple and experienced-based, the intermediate level is adaptive and duplicative in nature but is research-based, and the advanced level is innovative and risky but also research-based. Figueiredo (2002a) and Ariffin and Figueiredo (2004) refine Lall's classifications to absorb the industrial specification of technology. Rasiah (2004) further refines Lall's (1992) concept of capabilities to solely focus on technological capabilities, dropping investment capabilities in the process. Using a typology based on taxonomies and trajectories, this paper uses Rasiah's (2004) framework to measure the product and process technology capabilities. R\&D is arguably the most advanced technological activity carried out by firms. Product technological capabilities $(R D)$ include $\mathrm{R} \& \mathrm{D}$ expenditure as a percentage of sales and $R \& D$ personnel as a share of employment. The variable is measured as:

$$
R D=1 / 2[R D \exp , R D p e r]
$$

where $R D \exp$ and $R D$ per refer to $\mathrm{R} \& \mathrm{D}$ expenditure as percentage of sales and $\mathrm{R} \& \mathrm{D}$ personnel. 
Firm level competitiveness can also arise from the choice of process technology (PT) utilised in firms. PT is measured using the proxies of inventory control systems (ICS), age of machinery and equipment (ME) and process technology restructuring expenses in total sales (RE). As such, PT is measured as:

$$
P T=1 / 3[I C S, M E, R E] \text {, }
$$

whereby ICS, ME and RE refer to the number of inventory control systems, age of machinery and equipment and the percentage of restructuring expenses in total sales. The ME is measured using a scale of over 5 or more years which is equivalent to 0 ; $3-5$ years which is equivalent to $1 ; 2$ to less than 3 years which is equivalent to 2 and less than 2 years which is equivalent to 3 . ICS is measured arithmetically where each of the advanced inventory control system items of statistical process control (SPC), total preventive maintenance (TPM), just-in-time (JIT), international standards organisation (ISO), small group activity (SGA) and kaizen are given a score of one and added when a firm reported its use. The variable PT is normalised using the following formula:

$$
\text { Normalisation score }=\left(X_{i}-X_{\min }\right) /\left(X_{\max }-X_{\min }\right) \text {, }
$$

whereby $X_{i}, X_{\min }$ and $X_{\max }$ refer to the actual, minimum and maximum value of the related proxy of firm $i$, respectively. Normalisation allows for a comparable index to be established.

\subsubsection{Export intensity and performance}

There are a number of different measures of firm performance. Lall (2001) notes that it is relatively easier to define competitiveness for firms than for a country, stressing that the ability to perform better than other firms in sales, market share and profitability are good indicators. From the financial point of view, firm performance measurements include stock return, return on investment (ROI), internal rate of return (TRR) and Tobin's Q. Others include measures adopted in operational management and production economics literature such as price competitiveness, product quality, delivery and customer services (Avella et al. 2001; Vickery et al. 2003). Owing to limited data on profitability, this paper uses value added to comprehend the firm's performance (PE). Value added is measured as the difference between values of a firm's output and input. We use the log value of value added as the performance indicator. In examining export behavior, a large number of studies mainly use the ratio of exports over sales as one of the measures of export performance. In this paper, export performance uses exports intensity $(E I)$ which is the percentage of exports in total sales while size is measured by taking the log values of the number of employees.

\subsection{Partial least square method}

To test the hypotheses framed in the paper, the partial least square (PLS) method is used. Owing to insufficient supporting proofs on the issues of the mediating role of exports, analysis based on the ordinary least square algorithm is suitably used here. Indeed, Wold 
(1982) indicates that the method is best suited for analysing empirical data with insufficient supporting theories or with little available information. Moreover, the use of PLS is less rigid in variable normality and randomness and the estimated path coefficient is more flexible in sample size (Fornell, Bookstein 1982; Hulland 1999; Wold 1982). The effects of product and process technological capability on exports and performance are estimated separately using two separate models.

\section{Empirical results}

Table 2 and 3 show the results of the PLS structural model. The explained variance $\left(R^{2}\right)$, the standardised path coefficient and the $t$ values for both models, non-mediated and mediated, are calculated using the bootstrap approach. Similar to the standardised beta weight in regression analysis, the structural model is assessed by examining the significance of the path coefficients and the variances accounted for by the explanatory variables. Two models are presented to discuss the mediating effect of export intensity on the relationship between technological capability and performance. The effects of product and process technology capability (Tables 2 and 3 respectively) are estimated separately. The empirical results indicate that size influences significantly in a positive manner the product technology capability, export intensity and performance at the $1 \%$ level of significance. In addition, product technology capability and size influence significantly the export intensity of firms. The mediating model shows that exports significantly influence the performance of firms at the 5\% significant level, demonstrating that technology, exports and performance are interlinked directly and indirectly, thus validating the dynamic role played by technological capability. Moreover, size is found to link with all the three: technological capability, exports and performance. Hence, economics of scale plays an important role as predicted.

Table 2. R\&D, exports and performance

\begin{tabular}{|c|c|c|}
\hline \multirow[b]{2}{*}{ Effects on: } & \multicolumn{2}{|c|}{ Path Coefficient (b) ( $t$ value (bootstrap) } \\
\hline & Without mediating effects & With mediating effects \\
\hline $\begin{array}{l}\text { Endogenous Variable: RD } \\
\text { SIZE } \rightarrow \text { RD }\end{array}$ & $\begin{array}{c}0.443(6.182)^{* * * *} \\
R^{2}=0.197\end{array}$ & $\begin{array}{c}0.443(5.617)^{* * *} \\
R^{2}=0.197\end{array}$ \\
\hline $\begin{array}{l}\text { Endogenous Variable: EI } \\
\mathrm{RD} \rightarrow \mathrm{EI}\end{array}$ & & $0.141(2.697)^{* * *}$ \\
\hline $\mathrm{SIZE} \rightarrow \mathrm{EI}$ & & $\begin{array}{c}0.464(6.120)^{* * *} \\
R^{2}=0.293\end{array}$ \\
\hline $\begin{array}{l}\text { Endogenous: PE } \\
\mathrm{RD} \rightarrow \mathrm{PE} \\
\mathrm{SIZE} \rightarrow \mathrm{PE} \\
\mathrm{EI} \rightarrow \mathrm{PE}\end{array}$ & $\begin{array}{c}0.312(4.222)^{* * *} \\
0.435(9.440)^{* * *} \\
- \\
R^{2}=0.531\end{array}$ & $\begin{array}{c}0.285(3.481)^{* * *} \\
0.447(6.929)^{* * *} \\
0.190(2.520)^{* *} \\
R^{2}=0.557\end{array}$ \\
\hline
\end{tabular}

Notes: RD, EI, SIZE and PE are product technological capability, export intensity, firm's size, and performance, respectively. ${ }^{* * *} \mathrm{p}<0.01 ;{ }^{* *} \mathrm{p}<0.05$ (two tailed test). 
For process technology, size is not significant (see Table 3). In other words, regardless of size, even small and medium firms are equally adopting process technology. This is possible since the adoption of process technology does not require high investment in R\&D, which is consistent with the previously reported empirical evidence on Penang that found even small firms employ certain levels of process technology without any formal investments (Narayanan, Lai 2000; Rasiah 1994). Even the small and medium industries are forced to upgrade their process technology to secure contracts from multinationals. The system knowledge of process technology is also widely available via varied sources. Sources include the transfer of skilled and experienced workers, learning that takes place via training institutions like Penang Skill Development Corporation (PSDC) and web-based promotion of process techniques. However, size is found to be significant for exports and performance. Larger firms are found to export significantly more than small and medium firms with a consequent impact on economic performance. Process technology capability and export expansion are vital in driving performance. Similar to Model 1, both process technology capability and export expansion contribute positively and are found to be highly significant. Indeed, the variance improves when exports is treated as the mediating variable in the model.

Table 3. Process technology, exports and performance

\begin{tabular}{lcc}
\hline \multirow{2}{*}{ Effects on: } & \multicolumn{2}{c}{ Path Coefficient $(\beta)(t$ value (bootstrap) } \\
\cline { 2 - 3 } Endogenous Variable: PT & Without mediating effects & With mediating effects \\
SIZE $\rightarrow$ PT & $0.106(1.425)$ & $0.106(1.365)$ \\
& $R^{2}=0.011$ & $R^{2}=0.011$ \\
\hline Endogenous Variable: EI & & $0.148(1.698)^{*}$ \\
PT $\rightarrow$ EI & & $0.511(7.382)^{* * *}$ \\
SIZE $\rightarrow$ EI & & $R^{2}=0.299$ \\
& $0.222(3.126)^{* * *}$ & $0.193(2.797)^{* * *}$ \\
Endogenous: PE & - & $0.550(8.281)^{* * *}$ \\
PT $\rightarrow$ PE & & $0.196(3.008)^{* * *}$ \\
SIZE $\rightarrow$ PE & $R^{2}=0.502$ & $R^{2}=0.529$ \\
EI $\rightarrow$ PE & & \\
& &
\end{tabular}

Notes: PT, EI, SIZE and PE are process technological capability, export intensity, firm's size, and performance, respectively. ${ }^{* * *} \mathrm{p}<0.01 ;{ }^{* *} \mathrm{p}<0.05 ;{ }^{*} \mathrm{p}<0.10$ (two tailed test).

\section{Implications and conclusion}

The results in the paper suggest that there is a shared relationship among technology capability, exports and economic performance. On one hand, technological capability is found to correlate with both exports and economic performance directly while on the other hand, exports is found to influence performance indirectly via technological capability - both R\&D and process technology. Size is also found to play an important role in influencing product technology capability, exports and performance. Therefore, the results show that the scale of operation matters for electronics firms to adopt product 
technology, to export and to achieve better performance. The firms that engaged most in R\&D in Penang, e.g. Intel, Motorola, AMD, Osram, Agilent and National Semiconductor all employ over 1,500 workers. However, size does not matter in the utilisation of process technology as the results are not statistically significant. Clearly, as firms acquire and imitate (including creative) technologies, the initial development focusing on process technology does not seem to provide specific scale-based advantages for large-sized firms. The barriers facing initial entry and expansion in electronics through the use of frontier process technology appear low as small and medium firms enjoy similar capabilities as large firms.

Two important implications arise from this paper. First, methodologically and theoretically, in assessing the relationship among technological capability, exports and performance future researchers should consider the problem of endogeneity. For instance, technological capability could affect exports and performance, and at the same time exports could serve as the mediating variable as suggested by this paper. Also, size may influence all three variables in the role of R\&D capability. Second, technological capability (both product and process) development should be addressed when promoting exports among firms. Therefore, sustaining comparative advantage in an increasingly globalised world would require the government to formulate effective innovation systems that will encourage and facilitate technological upgrading. Given the significance of size, policies promoting exports should also address scale issues.

As usual, for any empirical studies, this paper is not without its limitations. In examining the relationship among innovation, exports and performance, we only explicitly consider size as one of the important variables. Previous research shows ownership and other firm-specific variables like age as potential determinants. Likewise, due to a lack of panel data, the causality between exports and innovation is not tested. Although the results established the direction of causality from innovation to exports, the relationship between the two is less clear. This paper assumes innovation to influence exports. Information from interviews shows that many firms engage in incremental innovation to sustain sales in export markets. For instance, firms improve the process capability to improve the quality of products that will be exported to markets such as Japan that demands quality goods ${ }^{2}$. Similarly, our interviews suggest that firms that acquire environment-friendly process technology (e.g. ISO 14000) have been able to penetrate the European markets ${ }^{3}$. It is our hope that the analysis can be taken further by incorporating other determinants in future studies. Also, panel data will be necessary to establish

\footnotetext{
${ }^{2}$ Without adequate process technology, firms were unable to meet the stringent quality required by the Japanese counterpart. Interviews with the logistic manager indicate that the export market share suffers if the Japanese counterpart rejects the shipment due to defects and standard quality checks. Therefore, to ensure that they meet the quality requirements, for the particular blocks of production, the machinery goes through extensive preventive maintenance before the production. Additionally, only qualified and experienced staff is used to handle the particular blocks of production. This shows that process improvements (even machine maintenance) are essential to secure export markets.

${ }^{3}$ In the electronic sector, the lead content requirement demands firms to implement a standard process technology. Therefore, we find that only firms which have such technology are able to penetrate the EU markets.
} 
causality between the variables. Similarly, the results are limited to the electronics firms in Penang and future research work should extend the scope to other sectors as well as locations. As such, it will provide more support and validate the findings of this study.

The empirical results based on the Partial Least Square (PLS) show that technological capability plays a multiple role in that it influences both the export and economic performance of a firm simultaneously. More importantly, we find evidence that exports acts as the mediating variable between technological capability (both product and process technology) and firm performance. Also, size is found to influence all three: product capability, exports and firm performance. This paper provides important insights for policy makers and contributes to the extensive literature that models the technologyexport-performance nexus. We suggest that future researchers consider the direct and indirect effects of technological capability on performance by considering exports as mediator and firm size as the control variables using panel data.

\section{Acknowledgement}

We are grateful to Khazanah Nasional for facilitating and supporting the collection of the firm-level data.

\section{References}

Abibullah, H. S.; Morshidi, S.; Kamarulazizi, I. 1994. Pemindahan teknologi dalam industri elektronik di Malaysia. Kuala Lumpur: Dewan Bahasa dan Pustaka.

Andersen, T. J.; Foss, N. J. 2005. Strategic opportunity and economic performance in mutlinational enterprises: the role and effects of information and communication technology, Journal of International Management 11(2): 293-310. http://dx.doi.org/10.1016/j.intman.2005.03.008

Andrews, K. 1971. The concept of corporate strategy. Homewood, IL: Richard D. Irwin.

Ariffin, N.; Bell, M. 1999. Firms, politics and political economy: patterns of subsidiary-parent linkages and technological capability-building in electronics TNC subsidiaries in Malaysia, in K. S. Jomo, G. Felker, R. Rasiah (Eds.). Industrial Technology Development in Malaysia: Industry and Firm Studies. London: Routledge, 150-190.

Ariffin, N.; Figueiredo, P. N. 2004. Internationalization of innovative capabilities: counter-evidence from the electronics industry in Malaysia and Brazil, Oxford Development Studies 32(4): $559-583$.

Audretsch, D. B.; Acs, Z. J. 1991. Innovation and size at the firm level, Southern Economic Journal 57(3): 739-744. http://dx.doi.org/10.2307/1059787

Avella, L.; Fernández, E.; Vázquez, C. J. 2001. Analysis of manufacturing strategy as an explanatory factor of competitiveness in the large Spanish industrial firm, International Journal of Production Economics 72(2): 139-157. http://dx.doi.org/10.2307/1059787

Barney, J. B.; Ouchi, W. 1986. Organizational economics: towards a new paradigm for studying and understanding organizations. San Francisco: Jossey-Bass Publishers.

Barney, J. B. 1991. Firm resources and sustained competitive advantage, Journal of Management 17(1): 99-120. http://dx.doi.org/10.1177/014920639101700108

Barney, J. B.; Wright, M.; Ketchen, D. J. 2001. The resource-based view of the firm: ten years after 1991, Journal of Management 27(6): 625-641. http://dx.doi.org/10.1177/014920630102700601 
Buckley, P. J.; Casson, M. 1991. The future of the multinational enterprise, $2^{\text {nd }}$ ed. Hampshire: Macmillan.

Cardozo, R.; McLaughlin, K.; Harmon, B.; Reynolds, P.; Miller, B. 1993. Product-market choices and growth of new businesses, Journal of Product Innovation Management 10(4): 310-340. http://dx.doi.org/10.1016/0737-6782(93)90075-2

Chandler, A. 1962. Strategy and structure. Cambridge, Massachusetts: MIT Press.

Chandy, R. K.; Tellis, G. J. 1998. Organizing for radical product innovation: the overlooked role of willingness to cannibalize, Journal of Marketing Research 35: 474-487.

http://dx.doi.org/10.2307/3152166

Cohen, W. M.; Klepper, S. 1996. A reprise of size and R\&D, The Economic Journal 106(437): 925-951. http://dx.doi.org/10.2307/2235365

Conner, K. R.; Prahalad, C. K. 1996. A resource-based theory of firm: knowledge versus opportunism, Organization Science 7(5): 477-501. http://dx.doi.org/10.1287/orsc.7.5.477

Dahlman, C. J.; Ross-Larson, B.; Westphal, L. E. 1987. Managing technological development: lessons from the newly industrializing countries, World Development 15: 759-775.

http://dx.doi.org/10.1016/0305-750X(87)90058-1

Delios, A.; Beamish, P. W. 1999. Geographic scope, product diversification and the corporate performance of Japanese firms, Strategic Management Journal 20(8): 711-727.

http://dx.doi.org/10.1002/(SICI)1097-0266(199908)20:8<711::AID-SMJ41>3.0.CO;2-8

Dhanaraj, C.; Beamish, P. W. 2003. A resource-based approach to the study of export performance, Journal of Small Business Management 41(3): 242-261.

http://dx.doi.org/10.1111/1540-627X.00080

Dosi, G. 1982. Technological paradigms and technological trajectories: a suggested interpretation of the determinants and directions of technical change, Research Policy 11(3): 147-162.

http://dx.doi.org/10.1016/0048-7333(82)90016-6

Duysters, G.; Hagedoorn, J. 2000. Core competencies and company performance in the worldwide computer industry, Journal of High Technology Management Research 11(1): 75-91.

http://dx.doi.org/10.1016/S1047-8310(00)00022-5

Ernst, D.; Ganiatsos, T.; Mytelka, L. (Eds.). 1998. Technological capabilities and export success in Asia. London: Routledge.

Figueiredo, P. N. 2002a. Does technological learning pay off? Inter-firm differences in technological capability-accumulation paths and operational performance improvement, Research Policy 31(1): 73-94. http://dx.doi.org/10.1016/S0048-7333(01)00106-8

Figueiredo, P. N. 2002b. Learning processes features and technological capability-accumulation: Explaining inter-firm differences, Technovation 22: 685-698.

http://dx.doi.org/10.1016/S0166-4972(01)00068-2

Fornell, C. R.; Bookstein, F. L. 1982. Two structural equation models: LISREL and PLS applied to consumer exit-voice theory, Journal of Marketing Research 19(4): 440-452.

http://dx.doi.org/10.2307/3151718

Geroski, P.; Machin, S.; Reenen, J. 1993. The profitability of innovating firms, RAND Journal of Economics 24(2): 198-211. http://dx.doi.org/10.2307/2555757

Graves, S. B.; Langowitz, N. S. 1993. Innovative productivity and returns to scale in the pharmaceutical industry, Strategic Management Journal 14: 593-605.

http://dx.doi.org/10.1002/smj.4250140803

Griliches, Z. 1986. Productivity, R\&D and basic research at the firm level in the 1970s, American Economic Review 76(1): 141-154.

Grossman, G. M.; Helpman, E. 1991. Innovation and growth in the global economy. Cambridge, MA: The MIT Press. 
Guan, J.; Ma, N. 2003. Innovative capability and export performance of Chinese firms, Technovation 23: 737-747. http://dx.doi.org/10.1016/S0166-4972(02)00013-5

Henderson, R. M.; Cockburn, I. M. 1994. Measuring competence: exploring firm-effects in pharmaceutical research, Strategic Management Journal 15: 63-84.

http://dx.doi.org/10.1002/smj.4250150906

Hirschman, A. O. 1958. The Strategy of Economic Development. New Haven: Yale University Press.

Hitt, M. A.; Ireland, R. D.; Lee, H. 2000. Technological learning, knowledge management, firm growth and performance: an introductory essay, Journal of Engineering and Technology Management 14(3/4): 231-246. http://dx.doi.org/10.1016/S0923-4748(00)00024-2

Hobday, M. 1996. Innovation in South-East Asial: lessons for Europe, Management Science 34(9): 71-81.

Hobday, M. 1999. Understanding innovation in electronics in Malaysia, in K. S. Jomo, F. Greg, R. Rasiah (Eds.). Industrial technology development in Malaysia: industry and firms studies. London: Routledge.

Hobday, M. 2005. Firm-level innovation models: perspectives on research in developed and developing countries, Technology Analysis \& Strategic Management 17(2): 121-146.

http://dx.doi.org/10.1080/09537320500088666

Hobday, M.; Rush, H. 2007. Upgrading the technological capabilities of foreign transnational subsidiaries in developing countries: the case of electronics in Thailand, Research Policy 36: 1335-1356. http://dx.doi.org/10.1016/j.respol.2007.05.004

Hulland, J. 1999. Use of partial least squares (PLS) in strategic management research: a review of four recent studies, Strategic Management Journal 20: 195-204.

http://dx.doi.org/10.1002/(SICI)1097-0266(199902)20:2<195::AID-SMJ13>3.0.CO;2-7

Iammarino, S.; Padilla-Perez, R.; von Tunzelmann, N. 2008. Technological capabilities and global-local interactions: the electronics industry in two Mexican regions, World Development 36(10): 1980-2003. http://dx.doi.org/10.1016/j.worlddev.2007.10.022

Ito, K.; Pucik, V. 1993. R\&D spending, domestic competition, and export performance of Japanese manufacturing firms, Strategic Management Journal 14(1): 61-75.

http://dx.doi.org/10.1002/smj.4250140107

Karagozoglu, N.; Lindell, M. 1998. Internationalization of small and medium-sized technologybased firms: an exploratory study, Journal of Small Business Management 36(1): 44-59.

Kim, L.; Nelson, R. (Eds.). 2001. Technology, Learning and Innovation: Experiences of Newly Industrializing Countries. Cambridge: Cambridge University Press.

Krugman, P. 1979. A model of innovation, technology transfer and the world distribution of income, Journal of Political Economy 87(2): 253-266. http://dx.doi.org/10.1086/260755

Krugman, P. 1986. Industrial organization and international trade, NBER Working Papers 1957. National Bureau of Economic Research, Inc.

Kumar, N.; Siddharthan, N. S. 1994. Technology, firm size and export behaviour in developing countries: the case of Indian enterprises, Journal of Development Studies 31(2): 289-309.

http://dx.doi.org/10.1080/00220389408422362

Lai, Y. W.; Narayanan, S. 1999. Technology utilization level and choice: the electronics and electrical sector in Penang, in K. S. Jomo, G. Felker, R. Rasiah (Eds.). Industrial technology development in Malaysia : industry and firm studies. London: Routledge, 107-124.

Lall, S. 1992. Technological capabilities and industrialization, World Development 20(2): 165186.

Lall, S. 1998. Technological capabilities in emerging Asia, Oxford Development Studies 26(2): 213-243. 
Lall, S. 2001. Competitiveness, technology and skills. Cheltenham: Edward Elgar.

Link, A. N. 1981. Research and development activity in US manufacturing. New York: Proger.

Lucas, R. J. 1988. On the mechanics of economic development, Journal of Monetary Economics 22(1): 3-42. http://dx.doi.org/10.1016/0304-3932(88)90168-7

McDougall, P. P.; Oviatt, B. M. 1996. New venture internationalization: strategic change and performance: a follow-up study, Journal of Business Venturing 11(1): 23-40.

http://dx.doi.org/10.1016/0883-9026(95)00081-X

Mittelstaedt, J. D.; Harben, G. N.; Ward, W. A. 2003. How small is too small? Firm size as a barrier to exporting from the United States, Journal of Small Business Management 41(1): 68-84. http://dx.doi.org/10.1111/1540-627X.00067

Narayanan, S.; Lai, Y. W. 2000. Technological maturity and development without research: the challenge for Malaysian manufacturing, Development and Change 31: 435-457.

http://dx.doi.org/10.1111/1467-7660.00161

Nelson, R. 1973. Recent exercises in growth accounting: new understanding or dead end?, The American Economic Review 63(3): 462-468.

Nelson, R. 1981. Research on productivity growth and productivity differences: dead end and new departures, Journal of Economic Literature 19: 1029-1064.

Nelson, R. 1991. Why do firms differ, and how does it matter?, Strategic Management Journal 12: 61-74. http://dx.doi.org/10.1002/smj.4250121006

Nelson, R. 2008. Economic development from the perspective of evolutionary economic theory, Oxford Development Studies 36(1): 9-21. http://dx.doi.org/10.1080/13600810701848037

Oyelaran-Oyeyinka, B.; Lal, K. 2006. Institutional support for collective learning: cluster development in Kenya and Ghana, African Development Review 18(2): 258-278.

http://dx.doi.org/10.1111/j.1467-8268.2006.00142.x

Pavitt, K. 1984. Sectoral patterns of technical change: towards a taxonomy and a theory, Research Policy 13(6): 343-373. http://dx.doi.org/10.1016/0048-7333(84)90018-0

Pavitt, K.; Robson, M.; Townsend, J. 1987. The size distribution of innovating in the UK 19451983, Journal of Industrial Economics 35: 291-316. http://dx.doi.org/10.2307/2098636

Penrose, E. T. 1959. The theory of the growth of the firm. New York: John Wiley.

Pla-Barber, J.; Alegre, J. 2007. Analysing the link between export intensity, innovation and firm size in a science-based industry, International Business Review 16: 275-293.

http://dx.doi.org/10.1016/j.ibusrev.2007.02.005

Rasiah, R. 2010. Are electronics firms in Malaysia catching up in the technology ladder?, Journal of Asia Pacific Economy 15(3): 301-319. http://dx.doi.org/10.1080/13547860.2010.494910

Rasiah, R. 1994. Flexible production systems and local machine tool subcontracting: electronics components transnational in Malaysia, Cambridge Journal of Economics 18(3): 279-298.

Rasiah, R. 2004. Technological intensities in East and Southeast Asian electronics firms: does network strength matter?, Oxford Development Studies 32(3): 433-455.

http://dx.doi.org/10.1080/1360081042000260610

Rasiah, R. 2006. Ownership, technological intensities, and economic performance in South Africa, International Journal of Technology Management 36(1/2/3): 166-189.

Rasiah, R. 2007. Export-orientation and technological intensities in auto parts firms in East and Southeast Asia: does ownership matter?, Asian Economic Papers 6(2): 55-76.

http://dx.doi.org/10.1162/asep.2007.6.2.55

Romer, P. 1986. Increasing returns and long-run growth, Journal of Political Economy 94(5): 1002-1037. http://dx.doi.org/10.1086/261420 
Romer, P. M. 1990. Endogenous technological change, The Journal of Political Economy 98(5): S71-S102. http://dx.doi.org/10.1086/261725

Rosenberg, N. 1982. Inside the black box: Technology and economics. Cambridge University Press: Cambridge.

Rosenberg, N.; Firschtak, C. (Eds.). 1985. International technology transfer; concepts, measure and comparisons. New York: Harper.

Scherer, F. M. 1984. Innovation and growth: schumpeterian perspectives. Cambridge, MA: MIT Press.

Schumpeter, J. A. 1934. The theory of economic development. Cambridge: Harvard University Press.

Shapira, P.; Youtie, J.; Yogeesvaran, K.; Jaafar, Z. 2006. Knowledge economy measurements: methods, results and insights from the Malaysian knowledge content study, Research Policy 35(10): 1522-1537. http://dx.doi.org/10.1016/j.respol.2006.09.015

Smith, A. 1776. The wealth of the nations. London: Strahan and Cadell.

Solow, R. 1957. Technical change and the aggregate production function, Review of Economics and Statistics 39: 312-320. http://dx.doi.org/10.2307/1926047

Solow, R. 1956. A contribution to the theory of economic growth, Quarterly Journal of Economics 70(1): 65-94

Sterlacchini, A. 1999. Do innovative activities matter to small firms in non-R\&D-intensive industries? An application to export performance, Research Policy 28: 819-832.

http://dx.doi.org/10.1016/S0048-7333(99)00023-2

Stock, G. N.; Greis, N. P.; Fischer, W. A. 2001. Absorptive capacity and new product development, Journal of High Technology Management Research 12(1): 77-91.

http://dx.doi.org/10.1016/S1047-8310(00)00040-7

Strandskov, J. 2006. Sources of competitive advantages and business performance, Journal of Business Economics and Management 7(3): 119-129.

Teece, D. J.; Pisano, G.; Shuen, A. 1997. Dynamic capabilities and strategic management, Strategic Management Journal 18: 509-533.

http://dx.doi.org/10.1002/(SICI)1097-0266(199708)18:7<509::AID-SMJ882>3.0.CO;2-Z

Tsai, K.-H. 2004. The impact of technological capability on firm performance in Taiwan's electronics industry, Journal of High Technology Management Research 15: 183-195.

http://dx.doi.org/10.1016/j.hitech.2004.03.002

Vickery, S. K.; Jayaram, J.; Droge, C.; Calantone, R. 2003. The effect of an integrative supply chain strategy on customer service and financial performance: an analysis of direct versus indirect relationship, Journal of Operations Management 21(5): 523-539.

http://dx.doi.org/10.1016/j.jom.2003.02.002

Wakelin, K. 2001. Productivity growth and R\&D expenditure in UK manufacturing firms, Research Policy 30: 1079-1090. http://dx.doi.org/10.1016/S0048-7333(00)00136-0

Wignaraja, G. 2002. Firm size, technological capabilities and market-oriented policies in Mauritius, Oxford Development Studies 30(1): 87-104.

Wignaraja, G. 2008a. Ownership, technology and buyers: explaining exporting in China and Sri Lanka, Transnational Corporations 17(2):1-15.

Wignaraja, G. 2008b. Foreign ownership, technological capabilities and clothing exports in Sri Lanka, Journal of Asian Economics 19: 29-39. http://dx.doi.org/10.1016/j.asieco.2007.12.001

Wold, H. 1982. Systems under indirect observation using PLS, in C. Fornell (Ed.). A second generation of multivariate analysis. New York: Praeger. 
Yeoh, P. L.; Roth, K. 1999. An empirical analysis of sustained advantage in the US pharmaceutical industry: impact of firm resources and capabilities, Strategic Management Journal 20: 637653. http://dx.doi.org/10.1002/(SICI)1097-0266(199907)20:7<637::AID-SMJ42>3.0.CO;2-Z

Young, A. 1928. Increasing returns and economic progress, Economic Journal 38(152): 527-542. http://dx.doi.org/10.2307/2224097

Zhao, H.; Li, H. 1997. R\&D and exports: an empirical analysis of Chinese manufacturing firms, The Journal of High Technology Management Research 8(1): 89-105. http://dx.doi.org/10.1016/S1047-8310(97)90015-8

V. G. R. CHANDRAN works as an Associate Professor at the Department of Development Studies, University of Malaya, Malaysia. He has also worked as a Principal Analyst of Economics and Policy Studies with Malaysian Industry-Government Group for High Technology, Prime Minister's Department, Malaysia. He holds a PhD in Economics and has held positions as a consultant and research associate with several international institutions. He conducts and leads research projects on industrial competitiveness, innovation and technology policy. He has published his research work in a number of international journals.

Rajah RASIAH holds the Khazanah Nasional Chair of Regulatory Studies at the Center of Regulatory Studies and he is a Professor of Innovation and Technology at the Department of Economics, University of Malaya. He holds a PhD from University of Cambridge and is a Professorial Fellow at the Maastricht Economic and Social Research and Training Centre on Innovation and Technology (MERIT), United Nations University. He has published a large number of papers in reputed national and international journals. 